\author{
Ishchuk, O. V., Deeva, T. V.
}

\title{
DIRECTED MOTIVATION AS A FACTOR INFLUENCING THE EFFICIENCY OF ORGANIZATIONAL STAFF'S ACTIVITIES
}

\begin{abstract}
Ishchuk, O. V. Deeva, T. V. Directed motivation as a factor influencing the efficiency of organizational staff's activities. The article defines the theoretical foundations of personnel motivation at the enterprise, presented definition of the term "directed motivation». The result of the study is an analysis of existing systems of motivation and their implementation in the realities of the Ukrainian economy. Presented an analytical study of existing systems directed motivation as a factor of influence the efficiency of activities staff of Ukrainian enterprises in a dynamic change. The conclusion with regard to modern enterprises and complex motivation measures on increasing the efficiency of labor, considering the peculiarities of many factors, which today affect every person in our country.
\end{abstract}

Keywords: directed motivation, influence, motivation, staff, enterprises, organization, management, efficiency, stimulation.

Ищук О. В., Деева Т. В. Направленная мотивация как фактор влияния на эффективность деятельности персонала предприятия. В статье определены теоретические основы мотивации персонала на предприятии, представлено определение понятия «направленная мотивация». Результатом исследования является анализ существующих систем мотиваџии труда и их применение в реалиях украинской экономики. Представлено аналитическое исследование существующих систем направленной мотивации как фактора влияния на эффективность деятельности персонала украинских предприятий в динамическом изменении. Сделан вывод о современных предприятиях и комплексных мотивационных мероприятиях для повыщения эффективности труда с учетом особенностей многих факторов, которые сегодня влияют на каждого человека в нашей стране.

Ключевые слова: направленная мотивация, влияние, мотивация, персонал, предприятие, организачия, руководство, эффективность, стимулирование.

Problem statement. Today, the personnel of Ukrainian enterprises are under the close observation of practitioners, HR managers, as well as researchers, theorists and practically oriented representatives of many scientific fields. One of the topical issues facing managers, executives and top management of Ukrainian and world organizations is the issue of improving the efficiency of employees of enterprises. There is no doubt that competent staff motivation contributes to improving the quality of staff and its relation to the organization as a whole. Consequently, we consider the actual direction for the modern organizational psychology of the study of directed motivation as a factor affecting the effectiveness of the personnel of the enterprise.

We believe that the directed motivation of the personnel at the enterprise is an excellent means for obtaining the maximum profit of the organization at the expense of selfless work, effective and economical use of resources (both material and non-material), disclosure of personnel potential, etc.

Analysis of recent research and publications shows that the problem of motivation was engaged by representatives of many sciences, but thoroughly psychology of motivation of the personnel was studied by such foreign researchers as F. Hertzberg [17], D. McGregor [19], D. McClelland [18], A. Maslow [13] etc. and Ukrainian researchers as D. Bohynya [3], S. Bondarenko [4], V. Gorban [5], O. Kovalenko [9], A. Kolot [11], S. Sardak [15], M. Semikina [3] and others.

It should be noted that during the history of the study of the psychology of motivation as such, almost every scientist touched on this issue. At the same time, the theory of motivation for enterprise workers has been actively developed since the XX-th century, although most motives, incentives and needs have long been known. At the present time, there are several different, but sufficiently substantiated motivation theories, which can be divided into three groups: primary (based on the 
historical experience of human behavior in the process of labor); meaningful (reflecting the content of needs) and procedural (studying the reward process) [8].

The purpose of the article is the analysis of the phenomenon of «motivation», «directed motivation» and research of directed motivation as a factor of influence on the efficiency of the personnel of the organization.

Presentation of the main material and research results. Usually, motivation is defined as a set of motives, incentives [8] or internal and external factors [5], or as a process of inducing a person to certain actions [9]. But we consider that the current use of motivational programs has long become something more than just motivation. Therefore, we propose a new wording that, in our opinion, reflects the essence of actual needs and requests for staff motivation professionals.

So, the directed motivation - is procedural system of incentive measures, which leads to the necessary and predetermined behavior of the employee. That is, the directed motivation is not an inductive process, which can either lead to an employee's efficiency improvement or not, depending on objective and subjective circumstances. Directed motivation has a clearly defined image of the future desired result and builds a system of measures that any employee induces to exact behavior.

Now, enterprises have a number of unresolved problems in stimulating effective work of personnel. We draw attention to the fact that more and more foreign investors come to Ukraine, who introduce their notions of production processes, results of labor and achievement of the goal of labor making a profit and social security for employees. Nowadays, for the majority of enterprises and organizations, a huge role plays the formation of new mechanisms of management, market oriented economy, and the saving parameters of production processes in rapidly changing external and internal environments [8]. For this purpose, it is necessary to form an effective system of personnel motivation, which corresponds to market conditions of management, and thereby ensure the successful operation and development of enterprises and the whole economy of the country.

To achieve the goal, we used the following methods: the secondary data analysis; the modified questionnaire «Analysis of Motivational Factors», made on the basis of two questionnaires to determine the existing structure of motivation and desirable for employees of the enterprise «Questionnaire for the analysis of motivational factors and needs» [1] and «Questionnaire for studying incentives» [2]; methods of mathematical processing of data with their subsequent qualitative interpretation and meaningful generalization.

\section{First stage of the study, method: secondary data analysis}

In the beginning, we will consider existing systems of directed motivation as a factor of influence on the effectiveness of the activities of Ukrainian enterprises using the method of secondary data analysis, namely data from empirical studies carried out by various agencies $[7 ; 10 ; 12 ; 14 ; 17]$ and published in Internet sources and scientific printed editions. So, we offer a dynamic picture of the development of motivational programs starting in 2006 and ending with 2018 among Ukrainian entrepreneurs.

Among the large enterprises of Ukraine in 2006, was conducted a research "Staff motivation schemes used by the companies working in Ukraine", about 1500 people from more than 420 enterprises took part in the research. It was found that the regarding to material motivation of employees, the following indicators are valid: $90 \%$ of bosses use rewards and bonuses as a major incentive to influence the effectiveness of their staff, the second place was the increase of wages $81 \%$ and mobile communication payment - is also $81 \%$. The third place among the material incentives was loans $-74 \%$, well, and in the last place - health insurance and company shares sales - by $13 \%$. Intermediate positions were: payment for petrol (58\%), payment for driveway or official car $(55 \%)$, free meals (52\%) etc. [10]. Among non-material motivation methods, it was found that $90 \%$ of entrepreneurs used corporate events as motivation, $84 \%$ believed that studying in trainings, verbal gratitude and friendly climate are motivating in the workplace, $81 \%$ of employers - feedback from the chief, $77 \%$ - career growth, and the last place was $23 \%$ - written gratitude. Intermediate positions occupied such answers as - involvement in decision-making (74\%), gifts for birthdays and other 
playdays (65\%), extra vacations (58\%), tour packages, relaxation and flexible working hours (36\%), payment for the second higher education (29\%), etc. [10].

We can say that in 2012 the situation with the use of motivational programs has changed cardinally, according to the results of the staff interviews about 200 enterprises of Ukraine, and now the first step in the directed motivation is headed by health insurance $-81 \%$, further - partial compensation of the insurance policy for employees and members of their families $-62 \%$, change of working schedule $-62 \%$ and the final in the ranking of the top three is the organization of nutrition in the office $-53 \%$. The last place was the rate of support for children of employees $-20 \%$, i.e. to help rest in a children's camp or sanatorium, providing fun leisure for children, etc. Intermediate steps were the following: celebrating family holidays (45\%), payment for a family doctor to employees (41\%), compensation for attending gyms and sports sections (37\%), money on a hobby (31\%), domestic affairs in the office (22\%), etc. [11].

In 2013, the company Work.ua, conducted a debriefing among users of this resource, exactly 500 respondents and found that $67 \%$ of Ukrainians consider money incentives as the best way to motivate them. With a significant gap, the second place was free education and training, for which $9 \%$ of respondents gave their votes. $7 \%$ of respondents appreciate the gratitude and recognition results of their work from the management. The last place was an extra weekend - only $3 \%$ of respondents consider this as a motivating factor. Intermediate responses related to personal gifts from the company (6\%), fines and punishment (5\%), corporate events (4\%), etc. [14]. But we would like to accent that this survey concerned exclusively the opinions of respondents, who took part in a study quantity by 500 people, but not motivation systems that are actually implemented at the enterprise. So, these results represent the picture if would like ordinary Ukrainians to see directed motivation and what, in their opinion, would have an impact on the effectiveness of the staff at the enterprise.

Another HR portal HeadHunter Ukraine in 2016 conducted its own research under the name «What inspire Ukrainians to work's feats. Motivation of the staff» [12] and the results of the survey show that in the first place - additional income $-70 \%$ respondents claiming that the main motivation is the increase of salary, bonuses and rewards. The main motivation for the $43 \%$ are interesting job tasks, and for $39 \%$ - the possibility of career growth in the company. In the last place among the motivating factors was the phenomenon as the corporate social responsibility of the enterprise $-6 \%$ of respondents. Intermediate responses pointed to a good collectivity, a good team, understanding by colleagues (29\%), appreciation and recognition of the work (28\% of respondents compared with 2013 , when this factor was among the top three), flexible working schedule (27\% compared to 2006 , when this factor had 36\%), company values (9\%), etc. [12].

A study in 2017 conducted by Work Service, portals Rabota.ua and LinkedIn shows that $47 \%$ of enterprises who participated in the survey are believe that personal approval from the manager motivates their employees, another $45 \%$ of enterprises use discounts on products and services of the company as motivation and $38 \%$ - trust on corporate events as an incentive for a more effective work. In the last place, with a score of $20 \%$, turned out to be competitions and games were the motivating events. Intermediate variants of components of motivational systems included the following versions: public gratitude to the employee (36\%), courses, trainings, personal coaches $(33 \%)$, regular information on the current situation in the company and participating in important meetings, the ability to influence management decisions (27\%), etc. [16].

From February to March 2018, research was conducted in the format of an online survey by a recruiting company HAYS, where was attended by representatives of international companies with a total of 3114 specialists and 486 employers. It was possible to identify the main material and nonmaterial factors of motivation. So, let's start with the material factors - the first place takes up a monetary reward $-93 \%$ respondents, the second place - bonuses for the goals met $-66 \%$, and in the third place $-59 \%$ - health insurance. In the last place $(20 \%)$ there was such a motivational factor as the improvement of the technical equipment of the workplace (computers, additional gadgets, etc.). Other answers to material motivational factors are as follows: compensation for additional professional training or language courses $(40 \%)$, providing car or compensation for transport costs $(32 \%)$, 
compensation for food or organizing free meals at work (31\%), individual rewards for work experience, for achievement, for loyalty, etc. (30\%), partial or full compensation of fitness, swimming pool or other sporting activities $(29 \%)$, extra weekends with obligatory payment (24\%), etc. [7].

What about for non-material factors of motivation of employees, it is fundamental for $63 \%$ of respondents have a professional development, $60 \%$ motivate the personality of the chief, and $56 \%$ are inspired by the opportunity to carry out diverse and interesting work tasks. The last thing people appreciate as a motivator is an open and friendly corporate culture $-42 \%$. Also among the variants were the possibility of career growth (55\%), competent and efficient management of the company (55\%), flexible working schedule (54\%), observance Work\&Life Balance $(49 \%)$, freedom in expressing opinions and suggestions (46\%), the opportunity to work from home (43\%), etc. [7].

So, summarizing the results of the first stage of the study, we can ascertain that the material motivation of employees was and remains the most important stimulus factor for increasing the efficiency of the personnel of Ukrainian enterprises.

\section{Second stage of the study, method: the questionnaire "Analysis of Motivational Factors"}

It was interesting for us to conduct our own research to find out the state of the problem and in the future to be able to develop an effective program of directed staff motivation. So, in 2018, we conducted a psychological study using the questionnaire «Analysis of Motivational Factors», made on the basis of two questionnaires to determine the existing structure of motivation and desirable for employees of the enterprise «Questionnaire for the analysis of motivational factors and needs» [1] and «Questionnaire for studying incentives» [2]. The respondents were 63 employees at a private enterprise in Zaporizhzhya, Ukraine. And it's interesting that almost all employees of the organization understand the motivation like cash rewards, which confirms the results of our first analytical study. The most important motivating factor is the level of salary $(84 \%)$, second place share opportunities for professional growth (52\%) and interesting work, diverse and non-standard work tasks $(52 \%)$, in the third place - the possibility of self-actualization (36\%). Therefore, among the three dominant operating motivational factors, there is also no material. In last place the best incentives to work there were loans $-12 \%$. Among other variant of incentives, there were additional payments for work experience at the company (35\%), additional training (courses, trainings, seminars, education) (35\%), corporate events (tickets to theaters, cinemas, concerts, trips to nature, excursions, including to other cities) and getting a subscription to a gym or swimming pool (32\%), free or partial payment of travel tour (28\%), payment road for to work place (pass, car maintenance) (26\%), free (at the expense of the enterprise) dinners $(16 \%)$, etc. [6, p. 66].

The second stage of our empirical study has confirmed that the main is the material incentive of staff in improving its effective activity in the enterprise.

Conclusions and perspectives of further research. It is important determine that for enterprises in Ukraine it is necessary to carry out complex measures to motivate increase of labor efficiency taking into account the peculiarities of the economic situation, the military actions, inflationary processes, social environment and other factors, which today have an impact on every person in our country.

The system of directed motivation should be focused on the final result, have a fair character and be simple and understandable for each employee. To achieve the best result of the enterprise, different types of motivation should be used together. It should remember that there is an individual motivation for individual workers, who deserve it and at the same time in a particular organization may not be determined once and for all a set of incentives, but there will be a system of directed motivation.

From the data presented in the article we see, that salary expectations of the staff grow, and employers, unfortunately, not ready to correspond them. The material motivation for today prevails in the desires and expectations of employees of organizations, but if it isn't possible to increase the bonus or salary, use not by material ways of motivation, such as the persuasion of employees that they are not indifferent to the company, each person is important for management, declare gratitude, publicly congratulate the best workers and let subalterns influence into strategic decisions, if that's important 
for them. Prospects for further research we see the development of a program of directed motivation and diagnostics of its influence on the efficiency of the staff of the enterprise.

\section{Список використаних джерел}

1. Анкета для анализа мотивационных факторов и потребностей [Электронный pecypc] // HR-Portal: HRСообщество и Публикации. - Режим доступа : http:/www.hr-portal.ru/tool/anketa-dlya-analiza-motivacionnyhfaktorov-i-potrebnostey

2. Анкета изучения поощрений [Электронный ресурс] // HR-Portal: HR-Сообщество и Публикации. - Режим доступа : http://www.hr-portal.ru/tool/anketa-izucheniya-pooshchreniy

3. Богиня Д. П. Трудовий менталітет у системі мотивації праці / Д. П. Богиня, М. В. Семикіна. - Кіровоград : Поліграф-Терція, 2002. - 226 с.

4. Бондаренко С. С. Внесення змін до мотивації персоналу як головна умова застосування концепції постійного вдосконалення на українських підприємствах / С. С. Бондаренко // Гуманізація соціального управління : тези доп. Всеукр. наук.-практ. конф., 29 квіт. 2008 р. - Х. : ФОП Александрова К. М., 2008. - С. 18-22.

5. Горбань В. Б. Використання мотиваційного потенціалу підприємства для формування дієвої системи мотивації працівників / В. Б. Горбань // Економіка та держава. - 2012. - № 5. - С. 108-112.

6. Іщук О. В. Система мотивації персоналу на прикладі приватного підприємства / О. В. Іщук // Проблеми сучасної психології : збірник наукових праць Державного вищого навчального закладу “Запорізький національний університет” та Інституту психології імені Г.С. Костюка НАПН України / за ред. С. Д. Максименка, Н. Ф. Шевченко, М. Г. Ткалич. - Запоріжжя : ЗНУ, 2018. - №1 (13). - С. 60-67.

7. Исследование мотивации сотрудников: для 60\% важна личность руководителя [Электронный ресурс] // NewsMir: Новости Украины и события в мире. - 2018. - Режим доступа : https://newsmir.info/1261742

8. Климчук А. О., Михайлов А. М. Маркетинг і менеджмент інновацій [Електронний ресурс] // Альона Олегівна Климчук, Андрій Миколайович Михайлов. - 2018. - № $1 . \quad$ - Режим доступу : http://mmi.fem.sumdu.edu.ua/http://mmi.fem.sumdu.edu.ua/sites/default/files/mmi2018_1_218_234.pdf

9. Коваленко О. В. Дослідження впливу стимулювання персоналу підприємства на продуктивність праці [Електронний ресурс] / О. В. Коваленко // Економічний вісник Запорізької державної інженерної академії. - 2016. Вип. 2. - С. 84-91. - Режим доступу : http://nbuv.gov.ua/UJRN/evzdia_2016_2_16.

10. Ковальчук І. В. Економіка підприємства [Текст] : навч. посібник / I. В. Ковальчук. - К. : Знання, $2008 .-679$ с. - (Вища освіта XXI століття).

11. Колот А. М. Мотивація, стимулювання й оцінка персоналу : навч. посіб. / А. М. Колот. - К. : КНЕУ. - 2012. $224 \mathrm{c}$.

12. Кращі мотивації на ринку праці України [Електронний ресурс] // Prostopravo.com.uа: все про права громадян та бізнесу в Україні. - опубліковано на сайті: 17.02.2016. - Режим доступу : http://ua.prostopravo.com.ua/pratsevlashtuvannya/novini/kraschi_motivatsiyi_na_rinku_pratsi_ukrayini_infografika

13. Маслоу А. Мотивация и личность / А. Маслоу. - [3-е изд.] ; пер. с англ. - СПб. : Питер, $200 \overline{0} 8 .-352$ с. (Серия «Мастера психологии»).

14. Результаты опроса: денежные поощрения - самый эффективный способ мотивации персонала [Электронный pecypc] // Work.ua. - 2013. - № 3. - Режим доступа : https://www.work.ua/news/ukraine/490/

15. Сардак С. Е. Мотивація та стимулювання працівників вітчизняних підприємств / С. Е. Сардак // Україна : аспекти праці. - 2008. - № 6. - С. 45-51.

16. Четыре тенденции в мотивации персонала, которые будут актуальны в 2017 году [Электронный ресурс] // Коммерческий директор: профессиональный журнал коммерсанта. - 2017. - Режим доступ: Источник: https://www.kom-dir.ua/article/1578-tendentsii-v-motivatsii-personala\#_=

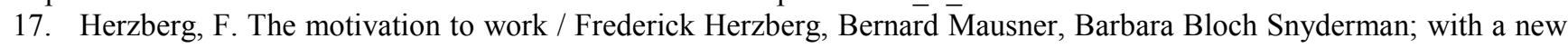
introduction by Frederick Herzberg. - New Brunswick, N.J., U.S.A. : Transaction Publishers, 1993. - 157 p.

18. McClelland, David, C. The achievement motive / David C. McClelland . - New York Appleton-Century-Crofts, 1953. -384 p. illus.

19. McGregor, D. The human side of enterprise / Douglas McGregor. - McGraw-Hill, 1960. - 246 p.

\section{Spysok vykorystanykh dzherel}

1. Anketa dlja analiza motivacionnyh faktorov i potrebnostej [Jelektronnyj resurs] // HR-Portal: HR-Soobshhestvo i Publikacii. - Rezhim dostupa : http://www.hr-portal.ru/tool/anketa-dlya-analiza-motivacionnyh-faktorov-i-potrebnostey

2. Anketa izuchenija pooshhrenij [Jelektronnyj resurs] // HR-Portal: HR-Soobshhestvo i Publikacii. - Rezhim dostupa : http://www.hr-portal.ru/tool/anketa-izucheniya-pooshchreniy

3. Bohynia D. P. Trudovyi mentalitet u systemi motyvatsii pratsi / D. P. Bohynia, M. V. Semykina. - Kirovohrad : Polihraf-Tertsiia, 2002. $-226 \mathrm{~s}$.

4. Bondarenko S. S. Vnesennia zmin do motyvatsii personalu yak holovna umova zastosuvannia kontseptsii postiinoho vdoskonalennia na ukrainskykh pidpryiemstvakh / S. S. Bondarenko // Humanizatsiia sotsialnoho upravlinnia : tezy dop. Vseukr. nauk.-prakt. konf., 29 kvit. 2008 r. - Kh. : FOP Aleksandrova K. M., 2008. - S. 18-22. 
5. Horban V. B. Vykorystannia motyvatsiinoho potentsialu pidpryiemstva dlia formuvannia diievoi systemy motyvatsii pratsivnykiv / V. B. Horban // Ekonomika ta derzhava. - 2012. - № 5. - S. 108-112.

6. Ishchuk O. V. Systema motyvatsii personalu na prykladi pryvatnoho pidpryiemstva / O. V. Ishchuk // Problemy suchasnoi psykholohii : zbirnyk naukovykh prats Derzhavnoho vyshchoho navchalnoho zakladu "Zaporizkyi natsionalnyi universytet” ta Instytutu psykholohii imeni H.S. Kostiuka NAPN Ukrainy / za red. S. D. Maksymenka, N. F. Shevchenko, M. H. Tkalych. - Zaporizhzhia : ZNU, 2018. - №1 (13). - S. 60-67.

7. Issledovanie motivacii sotrudnikov: dlja $60 \%$ vazhna lichnost' rukovoditelja [Jelektronnyj resurs] // NewsMir: Novosti Ukrainy i sobytija v mire. - 2018. - Rezhim dostupa : https://newsmir.info/1261742

8. Klymchuk A. O. Marketynh i menedzhment innovatsii [Elektronnyi resurs] // Alona Olehivna Klymchuk, Andrii

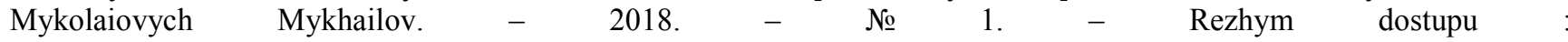
http://mmi.fem.sumdu.edu.ua/http://mmi.fem.sumdu.edu.ua/sites/default/files/mmi2018_1_218_234.pdf

9. Kovalenko O. V. Doslidzhennia vplyvu stymuliuvannia personalu pidpryiemstva na produktyvnist pratsi [Elektronnyi resurs] / O. V. Kovalenko // Ekonomichnyi visnyk Zaporizkoi derzhavnoi inzhenernoi akademii. - 2016. - Vyp. 2. - S. 8491. - Rezhym dostupu : http://nbuv.gov.ua/UJRN/evzdia_2016_2_16.

10. Kovalchuk I. V. Ekonomika pidpryiemstva [Tekst] : navch. posibnyk/ I. V. Kovalchuk. - K. : Znannia, 2008 . - 679 s. - (Vyshcha osvita KhKhI stolittia).

11. Kolot A. M. Motyvatsiia, stymuliuvannia y otsinka personalu : navch. posib. / A. M. Kolot. - K. : KNEU. - 2012. $224 \mathrm{~s}$.

12. Krashchi motyvatsii na rynku pratsi Ukrainy [Elektronnyi resurs] // Prostopravo.com.ua: vse pro prava hromadian ta biznesu V Ukraini. - opublikovano na saiti: 17.02.2016. - Rezhym dostupu : http://ua.prostopravo.com.ua/pratsevlashtuvannya/novini/kraschi_motivatsiyi_na_rinku_pratsi_ukrayini_infografika 13. Maslou A. Motivacija i lichnost' / A. Maslou. - [3-e izd.] ; per. s angl. $-\overline{\mathrm{SP}} \mathrm{b}$. : Piter, 2008. -352 s. (Serija «Mastera psihologii»).

14. Rezul'taty oprosa: denezhnye pooshhrenija - samyj jeffektivnyj sposob motivacii personala [Jelektronnyj resurs] // Work.ua. - 2013. - № 3. - Rezhim dostupa : https://www.work.ua/news/ukraine/490/

15. Sardak S. E. Motyvatsiia ta stymuliuvannia pratsivnykiv vitchyznianykh pidpryiemstv / S. E. Sardak // Ukraina : aspekty pratsi. - 2008. - № 6. - S. 45-51.

16. Chetyre tendencii v motivacii personala, kotorye budut aktual'ny v 2017 godu [Jelektronnyj resurs] // Kommercheskij direktor: professional'nyj zhurnal kommersanta. - 2017. - Rezhim dostup: Istochnik: https://www.kom-dir.ua/article/1578tendentsii-v-motivatsii-personala\#_=

17. Herzberg, F. The motivation to work / Frederick Herzberg, Bernard Mausner, Barbara Bloch Snyderman; with a new introduction by Frederick Herzberg. - New Brunswick, N.J., U.S.A. : Transaction Publishers, 1993. - 157 p.

18. McClelland, David, C. The achievement motive / David C. McClelland . - New York Appleton-Century-Crofts, 1953. -384 p. illus.

19. McGregor, D. The human side of enterprise / Douglas McGregor. - McGraw-Hill, 1960. - 246 p.

Іиук О. В., Дєєва Т. В. Спрямована мотивація як чинник впливу на ефективність діяльності персоналу підприємства. Сьогодні для українських підприємств є актуальним питання підвищення ефективності діяльності своїх співробітників. Ефективні мотиваційні програми сприяють підвищенню якості роботи працівників та їхнього ставлення як до праці, так $і$ до організації в ијілому. Отже, $в$ статті розглянуто актуальний напрям організаційної психології, а саме дослідження спрямованої мотивацї̈ як чинник впливу на ефективність діяльності персоналу підприємства.

Спрямована мотивачія персоналу на підприємстві є засобом, ще забезпечує отримання максимального прибутку організації за рахунок самовідданої прачі, ефективного та економічного використання ресурсів (як матеріальних, так і нематеріальних), розкриття кадрового потенціалу тощо. Визначено, що спрямована мотивачія - ие процесуальна система стимулюючих заходів, що приводить до необхідної та заздалегідь визначеної поведінки працівника.

Проаналізовано існуючі системи спрямованої мотивачії як чинника впливу на ефективність діяльності персоналу украӥнських підприємств в динаміці від 2006 року до 2018 року. Представлено найважливіші матеріальні та нематеріальні фактори мотиваџії, щзо впроваджено в організаціях України, серед яких премії та бонуси, підвищення заробітної плати, медичне страхування співробітників, корпоративні свята, навчання на тренінгах, усні подяки, дружній клімат, иікава робота, різнопланові й нестандартні робочі задачі, організація харчування в офісі та багато іншого. Висвітлено результати власного дослідження, щьо підтверджують результати попередніх досліджень, починаючи з 2006 року.

Ключові слова: спрямована мотивачія, вплив, мотивація, персонал, підприємство, організація, керівництво, ефективність, стимулювання. 


\title{
Відомості про автора
}

Іщук Ольга Вікторівна, кандидат психологічних, наук, доцент кафедри психології Запорізького національного університету, м. Запоріжжя, Україна.

Ishchuk, Olga Viktorovna, $\mathrm{PhD}$ of Psychology, Associate Professor, Department of Psychology, Zaporizhzhya National University, Zaporizhzhia, Ukraine.

E-mail: olga.ischuk@gmail.com

ORCID ID: https://orcid.org/0000-0003-2487-2180

Дєєва Тетяна Віталіївна, магістр 2 року навчання факультету соціальної педагогіки та психології Запорізького національного університету, м. Запоріжжя, Україна.

Deeva, Tetyana Vitaliivna, Master of Psychology at the Faculty of Social Pedagogy and Psychology, Zaporizhzhya National University, Zaporizhzhya, Ukraine.

E-mail: tankacrazy@gmail.com

ORCID ID: https://orcid.org/0000-0001-7404-1882

Отримано 1 листопада 2018 p. Рецензовано 17 грудня 2018 р. Прийнято 20 грудня 2018 р.

DOI (Article): https://doi.org/10.31108/2.2018.4.15.5

УДК 658.114.25:005.95.96:331.211.5:330.59 - 047.44

\author{
Л. М. Карамушка, О. І. Паршак
}

\section{ОЦІНКА ПРАЦІВНИКАМИ КОМЕРЦЙНИХ ОРГАНІЗАЦЙ РОЛІ ГРОШЕЙ У ЇХ ЖИТТЕДІЯЛЬНОСТІ: ЗВ'ЯЗОК ІЗ СОЦІАЛЬНО-ДЕМОГРАФІЧНИМИ ТА ОРГАНІЗАЦІЙНО-ПРОФЕСІЙНИМИ ХАРАКТЕРИСТИКАМИ ПРАЦІВНИКІВ}

Карамушка Л. М., Паршак О. І. Оцінка працівниками комерційних організацій ролі грошей у їх жситтедіяльності: зв'язок із соціально-демографічними та організаційно-професійними характеристиками працівників. У статті на основі емпіричного дослідження проаналізовано особливості оцінки працівниками комериійних організацій ролі громей у їх життєдіяльності, виявлено певні диспропориії в оцінці. Проаналізовано зв'язок між оцінкою працівниками комериійних організаџій ролі грошей у їх життедіяльності та сочіально-демографічними характеристиками прачівників (вік, сімейний стан, наявність дітей, стать). Досліджено зв'язок між оиінкою персоналом комериійних організачій ролі грошей у їх життедіяльності та організачійного-професійними характеристиками працівників (рівень освіти, загальний трудовий стаж, стаж роботи в компанії, посада в організачії). Визначено низку важливих напрямків оптимізащії ставлення до грошей у прачівників комериійних організаиій.

Ключові слова: комериійні організаиії; працівники комериійних організащій; оцінка працівниками комериійних організаиій ролі грошей у ӥх життєдіяльності; соиіально-демографічні характеристики працівників, організачійно-професійні характеристики пращуівників; напрямки оптимізачії ставлення до грошей персоналу комериійних організаџій.

Карамушка Л. Н., Паршак А. И. Оценка работниками коммерческих организаций роли денег в их жнизнедеятельности: связь с социально-демографическими и организационнопрофессиональными характеристиками работников. $B$ статье на основе эмпирического исследования проанализированы особенности оценки работниками коммерческих организаций роли денег в их жизнедеятельности, выявлены определенные диспропориии в оченке. Проанализирована связь между оценкой работниками коммерческих организачий роли денег в их жизнедеятельности $u$ 